\title{
Climate Imperialism: Ecocriticism, Postcolonialism, and Global Climate Change
}

\author{
Rachel Hartnett \\ https://orcid.org/0000-0002-2610-6570 \\ University of Florida, USA
}

\begin{abstract}
Global climate change threatens to kill or displace hundreds of thousands of people and will irrevocably change the lifestyles of practically everyone on the planet. However, the effect of imperialism and colonialism on climate change is a topic that has not received adequate scrutiny. Empire has been a significant factor in the rise of fossil fuels. The complicated connections between conservation and empire often make it difficult to reconcile the two disparate fields of ecocriticism and postcolonial studies. This paper will discuss how empire and imperialism have contributed to, and continue to shape, the ever-looming threat of global climate crisis, especially as it manifests in the tropics. Global climate change reinforces disparate economic, social, and racial conditions that were started, fostered, and thrived throughout the long history of colonization, inscribing climate change as a new, slow form of imperialism that is retracing the pathways that colonialism and globalism have already formed. Ultimately, it may only be by considering climate change through a postcolonial lens and utilizing indigenous resistance that the damage of this new form of climate imperialism can be undone.
\end{abstract}

Keywords: climate change, imperialism, colonialism, ecocriticism, postcolonialism, indigenous resistance, Tropics, empire

eTropic: electronic journal of studies in the tropics publishes new research from arts, humanities, social sciences and allied fields on the variety and interrelatedness of nature, culture, and society in the tropics. Published by James Cook University, a leading research institution on critical issues facing the world's Tropics. Free open access, Scopus Listed, Scimago Q1. Indexed in: Google Scholar, DOAJ, Crossref, Ulrich's, SHERPA/RoMEO, Pandora. ISSN 1448-2940. Creative Commons CC BY 4.0 free to download, save and reproduce. To cite, include: Author(s), Title of Paper, Editors (Eds.) Special Issue Title (Special Issue) eTropic, volume, issue, year, pages and DOI: http://dx.doi.org/10.25120/etropic.20.2.2021.3809 
eTropic 20.2 (2021) Special Issue: Tropical Imaginaries and Climate Crisis

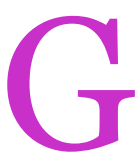

lobal climate change has been called the single greatest threat to human civilization. It threatens to kill or displace millions or even billions of people and will irrevocably change the lives of practically every human being on the planet. This topic has deservedly received much critical attention. The effects of imperialism and colonialism on climate change, however, is a topic that has not received adequate scrutiny. As Amitav Ghosh (2016) states: "[i]n accounts of the Anthropocene, and of the present climate crisis, capitalism is very often the pivot on which the narrative turns.... However, I believe that this narrative often overlooks an aspect of the Anthropocene that is of equal importance: empire and imperialism" ( $p$. 87). This lack of attention is not restricted to just environmental critics, as Rob Nixon (2011) points out in Slow Violence and the Environmentalism of the Poor, "postcolonial literary critics had, in turn, shown scant interest in environmental concerns" (p. 236). Dating back to the rise of coal during the Industrial Revolution, empire has been a significant factor in the rise of fossil fuels. This is no less true today as, for example, petro-imperialism remains a contributing factor in American foreign policy from Venezuela in Latin America to the Middle East. These complicated connections between conservation and empire also make it difficult to reconcile the disparate fields of ecocriticism and postcolonial studies. This paper will build on the work of Amitav Ghosh, Rob Nixon, Naomi Klein, Dipesh Chakrabarty, and Elizabeth DeLoughrey and George B. Handley to discuss how empire and imperialism have contributed to and continue to shape the ever-looming threat of climate crisis. Global climate change reinforces disparate economic, social, and racial conditions that developed, fostered, and thrived throughout the long history of colonization, inscribing climate change as a new, slow form of imperialism that is retracing the pathways that colonialism and globalism have already formed. Ultimately, it may only be by considering climate change through a postcolonial lens and utilizing indigenous resistance that the damage of this new form of climate imperialism can be halted.

There has already been significant work done to bridge the fields of ecocriticism and postcolonialism. In the introduction to their edited collected, DeLoughrey and Handley (2011) argue for a "sustained dialogue...between postcolonial and ecocritical studies" (p. 24) and go on to highlight several reasons why these fields have been kept disparate and the necessity for bringing them together. They contend that: "an ecological frame is vital to understanding how geography has been and still is radically altered by colonialism"; that postcolonialists are adept at "disentangling the hierarchies" formed through colonial binarism; furthermore that postcolonial studies prioritizes sustainability and "the health of the physical world"; and that "the field of postcolonial studies has long been engaged with questions of agency and representation of the nonspeaking or subaltern subject" (DeLoughrey \& Handley, 2011, pp. 24-25). Chakrabarty (2012) expands upon these arguments to 
eTropic 20.2 (2021) Special Issue: Tropical Imaginaries and Climate Crisis

claim that postcolonialism complicates the configuration of the Anthropocene "of humans as constitutively one - a species, a collectivity whose commitment to fossilfuel based, energy-consuming civilization is now a threat to that civilization itself' to include "the contingency of individual human experience; belonging at once to differently-scaled histories of the planet, of life and species, and of human societies" (p. 2, 14). This is significant because anthropological differences necessitate deconstructing humanity into groups with varying political, economic, and social power, especially given "the uneven impacts of climate change" (Chakrabarty, 2012, p.14). Chakrabarty's argument that within the study of global climate change humanity cannot be subsumed into a monolithic group lays the theoretical framework for this article. Different cultural groups have contributed to ecological destruction to varying degrees and the impact of climate change will indeed be distributed unevenly. However, I am further arguing for the necessity of postcolonial and anticolonial work within any study of climate change because its impacts will be distributed not just unequally, but in a direct echoing of colonial pathways.

Global climate change is a form of slow violence. Slow violence is "a violence that occurs gradually and out of sight, a violence of delayed destruction that is dispersed across time and space, an attritional violence that is typically not viewed as violence at all" (Nixon, 2011, p. 2). This includes the current climate crisis due to "the thawing cryosphere, toxic drift, biomagnification, deforestation, the radioactive aftermaths of wars, acidifying oceans, and a host of other slowly unfolding environmental catastrophes" which rank among the examples of slow violence (Nixon, 2011, p. 2). What separates slow violence from other forms of violence is that it "is neither spectacular nor instantaneous, but rather incremental and accretive, its calamitous repercussions playing out across a range of temporal scales" (Nixon, 2011, p. 2). It becomes imperative to view climate change in these parameters when you consider the already recognized victims of climate change:

Obviously, elsewhere in the world there are already victims of climate change. 300,000 deaths according to the U.N. 300,000 people in the Horn of Africa, in Bangladesh, India, Vietnam... But those deaths are due to the exacerbation of already existing problems. Drought, malnutrition, floods. Nothing seemingly 'climatic.' Furthermore, the victims of climate change die slowly, one after another-no drama, no media coverage-scattered over the whole year over the whole planet. If only they had the good sense all to die on the same day, like the victims of the 2004 tsunami. That would catch our attention. Those everyday deaths don't have the same weight as a large death toll on a single day... Little lives. In little boxes. And we don't notice a thing. (Squarzoni, 2014, pp. 250-1) 
eTropic 20.2 (2021) Special Issue: Tropical Imaginaries and Climate Crisis

Squarzoni is describing the deaths of hundreds of thousands of people but is supremely concerned with the fact that these deaths are taking place on a temporal scale that is too long for most of us to adequately grasp. If the deaths were instantaneous, they would become the spectacle that marks traditional forms of violence. However, these first victims of climate change are the victims of a slow violence, which marks them as invisible. Despite the temporal differences between a quick violence, like military conflicts and forms of enslavement typical of colonization, and the slow violence of allowing the causes of global climate change to go largely unchallenged, climate change will nevertheless follow the same route and processes of imperialism.

It is imperative to begin any discussion of global climate change with an examination of the ways in which the tropics will be among the first to suffer from its effects. As a form of slow violence, climate change will disproportionately affect poor and postcolonial nations, most of which are in the tropics. The vast majority of the waves of colonization since the $16^{\text {th }}$ century have happened within the tropics. This imperial period began with the voyages of Christopher Columbus, who stumbled upon the Caribbean in his quest to find an alternate trade route to Asia. The tropics have formed the foundation of colonial possessions since that time, also serving as primary sites for plantations and the forced enslavement of Africans to work on said plantations. That being said, this "environmentalism of the poor" compounds the disaster those of the tropics face because "it is those people lacking resources who are the principal casualties of slow violence. Their unseen poverty is compounded by the invisibility of the slow violence that permeates so many of their lives" (Nixon, 2011 , p. 4). This is significant because many postcolonial nations tend to be poorer because they were robbed of resources during the colonial period and because their infrastructures were designed primarily for the benefit of resource extraction, not for sustainability and repair. As Albert Memmi (1991) asserts: "colonization weakens the colonized and that all those weaknesses contribute to one another. Nonindustrialization and the absence of technical development in the country lead to a slow economic collapse of the colonized" (p. 115).

Additionally, Western civilizations are among the leading contributors to carbon emissions on a per capita basis of population. Canada, the United States, Russia, and the European Union are four of the five worst contributors in emissions per capita. In fact, "Canada, the United States, and Russia emit more than double the global average per person" (Ge et al., 2014). Yet, nations within the tropics rank quite low on the list of emissions per capita. Squarzoni (2014) also points this out, saying that in order to reduce global carbon dioxide emissions to "3 gigatons of carbon equivalent a year" a global population of 6 billion people would each have to produce less than " 1,000 pounds $(500 \mathrm{~kg})$ of carbon equivalent per person per year" 
eTropic 20.2 (2021) Special Issue: Tropical Imaginaries and Climate Crisis

(pp. 188-9). He uses the specific example of Mali, a tropical nation, where "the average person's consumption produced emissions of 22 pounds $(10 \mathrm{~kg}$ ) of carbon equivalent a year" while "[t]he average French person produced 2.7 tons a year" and Americans "produced an average of 6.8 tons per person per year" (Squarzoni, 2014, p. 189). Despite this, the tropics and other postcolonial areas will be the most rapidly affected by global climate change.

While nations of the Western world continue to be among the largest per capita emitters of carbon equivalents, it has become apparent that the countries that will suffer the most immediate effects of climate change are ones that were formerly colonized. As Lundberg (2020) articulates, the "predicted increase of El Niño events which transform weather around the global tropics and subtropics" will lead to "excessive rainfall in some regions and droughts in others" (2). Furthermore, Klein (2014) points out that:

Four degrees of warming could raise global sea levels by 1 or possibly even 2 meters by 2100 (and would lock in at least a few additional meters of rise over future centuries). This would drown some island nations such as the Maldives and Tuvalu, and inundate many coastal areas from Ecuador and Brazil to the Netherlands to much of California and the northeastern United States, as well as huge swaths of South and Southeast Asia. (p. 13)

Of the many locations Klein lists, it is striking how many are postcolonial nations. Of particular note for this article are the multiple tropical nations. Of the countries listed, only the Netherlands and the United States hold the position of colonizer rather than colonized. ${ }^{1}$ Postcolonial nations are still struggling through the consequences and legacies of decolonization (and the current effects of neocolonialism) and others remain territories of the countries that took them by force. These legacies of imperialism and decolonization are being exacerbated and prolonged through climate change. The West will see very few of the immediate effects while postcolonial nations will face death and destruction.

The Caribbean and other island nations will also be transformed by climate crisis. These islands are at risk from not only sea level rise, but-as with the increase in cyclonic activity in the Arabian sea-they are also especially vulnerable to the worldwide increase in hurricane and cyclonic activity. An example of this is the slew of powerful hurricanes that have battered the islands of the Caribbean within the last few years, including Hurricane Maria in September 2017, which caused substantial

\footnotetext{
1 The United States, in addition to their external colonization beginning at the end of the nineteenth century, was formed through the settler colonialization of the North American continent.
} 
eTropic 20.2 (2021) Special Issue: Tropical Imaginaries and Climate Crisis

damage in Puerto Rico, the Dominican Republic, Haiti, and the U.S. Virgin Islands. These countries and territories have had some of the longest exposure to imperialism, dating back to the voyages of Christopher Columbus. Puerto Rico was "[c]laimed for Spain by Christopher Columbus on his second trip to the New World" before being "taken along with Cuba by the U.S. in the 1898 Spanish-American War" (Vick, 2017). These consistent and consecutive colonialisms left the Caribbean-and other postcolonial sites-with poor infrastructure and bereft of resources. An example of how climate change reinscribes colonial structures can be seen through Hurricane Maria.

In September 2017, Hurricane Maria tore through the Caribbean, striking "Puerto Rico on September 20 with 155 mph winds and a central pressure of 917 millibars" ("Hurricane Maria 2017," n.d.). To many, Hurricane Maria and the other uncommonly strong recent hurricanes can be seen as a result of climate change since their ferocity is influenced by the warmer waters in the Atlantic. Although many climate scientists are reluctant to blame individual weather phenomenon directly on climate change, and rightfully so, some have begun to make these claims, including Climate Nexus, who argue the "record-breaking rainfall and flooding driven by Hurricane Maria - as well as Hurricanes Harvey and Irma just weeks before-is consistent with the long-term trend driven by climate change" (Hurricane Maria 2017, n.d.). While the storms themselves may be natural, their intensity and frequency are very likely increased because of global climate change. The massive amount of damage inflicted upon Puerto Rico and major portions of the Caribbean further repeats the traumatic legacies of imperialism. As of the end of 2017, "more than 660,000 power customers across Puerto Rico still lack[ed] electricity more than three months after Hurricane Maria" (Coto, 2017). In 2021, a U.S. Department of Housing and Urban Development special investigation revealed that the Trump administration purposefully delayed "approximately $\$ 20$ billion in disaster-recovery funds that Congress appropriated to help Puerto Rico" (Office of Special Investigations, 2021, p. 2). While the U.S. mainland quickly returned to relative normality after the storm, Puerto Rico is still suffering underfunding for rebuilding efforts. As with climate change as a whole, the colonizing nation did not feel the adverse effects to nearly the degree of the colonized. This also reiterates the point that in many ways forgetting is a form of privilege, one only accessible to the colonizer. The U.S. can forget about Hurricane Maria. The Caribbean cannot. This divide continues to exacerbate power inequities between nations and their colonial possessions, as well as between former colonizing nations (who have frequently transitioned into neocolonial nations) and postcolonial ones.

Considering the catastrophic damage Hurricane Maria inflicted on Puerto Rico and the Caribbean as a whole, the question could be raised: Has climate change moved 
from slow violence to a new mode of violence? Does the massive amount of damage and loss of life show that climate change is now a form of spectacular, rapid violence? Nixon (2011) argues that media has a "bias toward spectacular violence" (p. 4). This spectacular violence, in direct opposition to slow violence, happens quickly, draws a lot of media attention, and is seen on a catastrophic scale. Slow violence is given "unequal attention" because "[i]n an age that venerates instant spectacle, slow violence is deficient in the recognizable special effects that fill movie theaters and boost ratings on TV" (Nixon, 2011, p. 6). Yet this notion of movie theatre visuals describes the initial media and popular responses to Hurricane Maria and Puerto Rico. This could be interpreted as suggesting that Hurricane Maria, and possibly climate change itself, are moving out of the slow phase of violence. However, within just a few months of Hurricane Maria making landfall in Puerto Rico the coverage of the disaster quickly dissipated. Probable effects of climate change can be a spectacle for a short period (during the catastrophic weather events, for example) but cannot be maintained-at least until it is far too late. Just because in rare cases climate change presents as a spectacle, does not mean it sustains spectatorship; and it quickly resumes a pattern of slow violence. Furthermore, as Nixon articulates in an interview with the Harvard University Press (2013), the measure of slowness is one of an overall, global rate. This is particularly important for catastrophes, like Hurricane Maria, where the corporate media presents "increasingly extreme events...in isolation, whereas in the aggregate they could be used to occasion bold, ongoing coverage of the incremental, but profoundly consequential climate changes that are occurring" (Nixon, 2013). Thus, although there are instances of spectacle or accelerations within Nixon's framework of slow violence, it remains difficult to present a global and sustained emphasis on this violence.

Furthermore, the treatment of Puerto Rico by the U.S. government after the initial catastrophe, demonstrates the disposability of postcolonial citizens. The purposeful denial of resources to the country following the disaster and the "markedly slower and less attentive" response to Hurricane Maria in Puerto Rico versus the responses to Hurricanes Harvey and Irma in Texas and Florida respectively, left many Puerto Ricans, and those sympathetic with their plight, with the message "that a population of brown-skinned, Spanish-speaking Americans counts for less" (Vick, 2017). This treatment of people as disposable supports the idea that Hurricane Maria still functions as a form of slow violence. Additionally, the treatment of casualties from Hurricane Maria also shows that climate change and its effects remain a form of slow violence. The official death toll in Puerto Rico listed only 64 casualties. However, these are just the spectacular deaths. The real death toll, calculated over a slower temporal scale, includes those who died from lack of medical attention, complications from injuries, and other deaths brought about from lack of electricity, 
eTropic 20.2 (2021) Special Issue: Tropical Imaginaries and Climate Crisis

food, and clean water, as well as those whose health and lives will be diminished by long-term effects of the storm. The New York Times found "that in the 42 days after Hurricane Maria made landfall...1,052 more people than usual died across the island" (Robles et al., 2017). The final death toll for the island was 2,975, "nearly 50 times the previous estimate of 64" (BBC News, 2018). This harkens back to Squarzoni's point about the already existent victims of climate change: "If only they had the good sense all to die on the same day, like the victims of the 2004 tsunami. That would catch our attention. Those everyday deaths don't have the same weight as a large death toll on a single day" (2014, p. 250). Therefore, despite spectacular initial attention, climate change and its catastrophic climatological effects are still very much elements of slow violence.

Besides the risk of sea level rise and increased meteorological storm systems, postcolonial nations also have another increased risk factor: disease. For the most part, poor or developing countries lack the resources to effectively combat new illnesses. Global climate change brings a rise in average global temperatures, and higher temperatures increase the geographic area of vector-borne illnesses, largely due to forced migration of animals (Squarzoni, 2014). These new animals will bring diseases to populations that either do not have access to vaccines or do not have natural immunity due to exposure. When higher global temperatures allow for the increased spread of vector-borne illnesses, "220 to 400 million more people could be exposed to Malaria. Yellow Fever, Dengue Fever, and Lyme Disease could become endemic to the middle latitudes. In developing countries, the health repercussions of warming will be harsher on poorer populations. Once again, climate change exposes the problem of income disparity" (Squarzoni, 2014, p. 253). Although many of these illnesses could become common in imperial and formerly imperial nations as well, it is the poorer nations that will suffer the most in the near and middle-term. Many developing countries also do not have adequate resources-like electricity or running water-let alone money to provide health resources like immunization and mosquito netting. This poverty is not only a direct legacy of extractive colonialism, but furthermore, economic exploitation and globalization continue to haunt these nations and "[t]he economic effect of large multinational companies and the existence of high levels of debt in developing countries have maintained a version of economic colonial power" (Edwards, 2008, p. 161). As Leon Sealy-Huggins (2017) states in his article, ' $1.5^{\circ} \mathrm{C}$ to Stay Alive': Climate Change, Imperialism and Justice for the Caribbean, "wealth expropriated from the Caribbean during the period of early colonialism was expended on processes of industrialization, which has in turn contributed significantly to the climate change-inducing emissions that now threaten Caribbean societies" (p. 2445). Colonization stole wealth and economic prosperity from much of the Caribbean and other tropical countries as it made colonizers rich. Now the effects of this income disparity will create problems of disease as global 
eTropic 20.2 (2021) Special Issue: Tropical Imaginaries and Climate Crisis

temperatures rise. Colonization continues to shape the ways in which nations will suffer from global climate change, re-inscribing imperialism.

As Western nations are struggling to decrease their carbon footprint, many postcolonial nations are still trying to industrialize to reach a better standard of living. Unfortunately, it is the "energy model of the wealthier countries [that] is becoming the future path of the developing countries, which want to catch up with energyintensive, accelerated growth" (Squarzoni, 2014, p. 364). Most energy experts assert that for these developing nations, "[t]o develop infrastructures for education, health...the existing models of the industrialized countries shouldn't be replicated, because they're very energy intensive and consume a great deal of raw materials" (Squarzoni, 2014, p. 365). However, these sorts of restrictions have been met with resistance from some developing countries. In fact, many "green or environmental discourses were once frequently regarded with skepticism as neocolonial, Western impositions inimical to the resource priorities of the poor in the global South" (Nixon, 2011 , p. 4). This skepticism has historical roots. In India, when the native population began to industrialize at a rate that would have made them equal to British industrial advancements, Britain passed laws that prevented India from developing technologically. As the colonial force in India, "the emerging fossil-fuel economies of the West required that people elsewhere be prevented from developing coal-based energy systems of their own, by compulsion if necessary" (Ghosh, 2016, p. 107). It is understandable that nations held back or confined by previous colonial restrictions regarding industrialization would feel apprehensive about Western, developed, countries making decisions on their technological advancement today. Although the concern with which Western countries are trying to prevent increased carbon emissions may be sincere, within the historical context it is not hard to see why developing countries often view the West's interference as neocolonial. Furthermore, Sealy-Huggins (2017) argues that within the Caribbean, the "vulnerability to these impacts [of climate change]....is not reducible to location or the globally uneven distribution of the maladies of climate change" and that the only way to truly "understand these existential threats [is] by recognizing that some Caribbean states are among the most indebted globally, an indebtedness that is itself traceable to relations of colonialism and imperialism" (p. 2445). By refusing to acknowledge the economic disadvantage imperialism created for much of the Global South, imperial and former imperial nations turn a blind eye to their past actions and the inequalities that arose because of them.

These inequalities are exactly why some postcolonial nations are seeking reparations to industrialize and help prevent increased carbon emissions that will hasten global climate change. The effects of colonization and the theft of land, resources, and labor still shape economic situations within the developing world. As 
eTropic 20.2 (2021) Special Issue: Tropical Imaginaries and Climate Crisis

Klein (2014) points out, the idea that the actions of our forefathers should not play a role in modern political or social policy "overlooks the fact that those past actions have a direct bearing on why some countries are rich and others poor" (p. 414). This concept is not new among economists or even environmental justice activists: "In Latin America progressive economists have long argued that Western powers owe an 'ecological debt' for centuries of colonial land grabs and resource extraction, while Africa and Caribbean governments have, at various points...called for reparations to be paid for transatlantic slavery" (Klein, 2014, p. 414). These economic reparations are necessary if the West expects the Global South to industrialize without further contributing to the damage caused by carbon emissions. Sealy-Huggins (2017) argues that "the expropriation of wealth and resources used to enrich colonial and imperial societies in general" requires economic reparations "as redress for the global inequalities resulting from this appropriation of wealth" (p. 2452). Developing countries are "squeezed between the impacts of global warming, made worse by persistent poverty, and by their need to alleviate that poverty, which, in the current economic system, can be done most cheaply and easily by burning a great deal more carbon, dramatically worsening the climate crisis" (Klein, 2014, p. 416). Since so much of the poverty in these regions is the result of the long history of imperialism, which enriched the colonizing countries and aided in their rise to economic prosperity, it is only fair that these rich imperial nations pay back the developing world for the resources and economic prosperity stolen from them.

Even if reparations are paid to aid developing nations, the world has now reached a threshold of carbon emissions that makes significant climatological changes impossible to avoid. Since the rapidly approaching effects of climate change by Western countries will have a much worse and more immediate effect on postcolonial regions, climate change should be seen as an extension of the colonial history already tied to coal and fossil fuels. The rise of fossil-fuels is steeped in imperial history, so much so that Klein (2014) comments on "[t]he braided historical threads of colonialism, coal, and capitalism" (p. 176). Coal, the first major fossil fuel, grew into a massive industry in the West in part due to the slave trade: "when the British Parliament ruled to abolish slavery in its colonies in 1833, it pledged to compensate British slave owners for the loss of their human property-a backward form of reparations for the perpetrators of slavery, not its victims" (Klein, 2014, pp. 415-6). Many of these payouts, which amounted to £20 million,

went directly into the coal-powered infrastructure of the now roaring Industrial Revolution-from factories to railways to steamships. These, in turn, were the tools that took colonialism to a markedly more rapacious stage, with the scars still felt to this day. (Klein, 2014, p. 416) 
eTropic 20.2 (2021) Special Issue: Tropical Imaginaries and Climate Crisis

Klein is careful to distinguish that coal and a society based on fossil-fuels did not cause colonization or create inequality in the world. What can be argued, however, is that as "coal helped Western nations to deliberately appropriate other people's lives and lands" it allowed "these same nations the means to inadvertently appropriate their descendants' sky as well, gobbling up most of our shared atmosphere's capacity to safely absorb carbon" (Klein, 2014, p. 416). Klein is making a direct comparison here between imperialism and climate change. Both directly reduced the quality of lives of future generations due to greed and selfishness. Sealy-Huggins (2017) says this more directly, claiming that, within the Caribbean, "the political and social relations of climate change....are significantly patterned by contemporary forms of imperialism, as well as by the historical legacies of imperialism and colonialism", and that "neoliberal modes of development via climate finance instruments shows that these are poised to exacerbate imperialism's legacy of exploitation" (p. 2453). Neoliberalism threatens to exacerbate or re-inscribe the effects of imperialism on the Caribbean, and other former colonized countries, particularly through economic means. Climate finance instruments are a means for financial corporations to leverage the adverse effects of climate change. Western economic markets will once again profit off postcolonial nations as they insure their profits despite global climate change.

A large portion of the work being done to forestall or minimize the damage of climate change is contained within the biological and environmental sciences. Ultimately, that climate change re-inscribes imperialism should be anticipated because of the link between conservation and colonization. The protection of America's wildlife and natural landscapes through the formation of the national parks is widely regarded as the beginning of the conservation movement. The creation of the national parks also coincided with the removal of indigenous Americans from those 'preserved lands' and their displacement onto reservations. As Mark David Spence illustrates in his book, Dispossessing the Wilderness: Indian Removal and the making of the National Parks, the foundation of the national park system was based on the ideology that presented the "wilderness as an uninhabited Eden that should be set aside for the benefit and pleasure of vacationing Americans" (1999, p. 4). This configuration of the national lands as uninhabited had one major flaw: the native peoples who "continued to hunt and light purposeful fires in such places" (Spence, 1999, p. 4). In order to fulfill the preservationist view, "the establishment of the first national parks necessarily entailed the exclusion or removal of native peoples" since "uninhabited wilderness had to be created before it could be preserved" (Spence, 1999, p. 4). Three of the major national parks-Yosemite, Yellowstone, and Glacier-had "policies of Indian removal" despite the fact that "each supported a native population at the time of its establishment" (Spence, 1999, p. 5). This treatment of the 
eTropic 20.2 (2021) Special Issue: Tropical Imaginaries and Climate Crisis

indigenous North American population is in line with settler colonial ideology. More insidious, however, is how this settler colonial project would begin global conservation efforts. The United States became a leader in conservation and preservationist efforts, and the national parks "as the grand symbols of American wilderness, the uninhabited landscapes preserved in these parks have served as models for preservationist efforts, and native dispossession, the world over" (Spence, 1999, p. 5). This further illustrates the ways in which modern understandings of environmentalism, preservation, and conservation have been shaped by colonialism-settler colonialism in this specific case.

With the dubious imperial beginnings of conservation and environmentalism, it is not surprising that ecocriticism also has problematic roots. Nixon (2011) scrutinized the lack of international writers within ecocritical literature and found that the current slew of ecocritical work "tended to canonize the same self-selecting genealogy of American authors" (p. 235). He says that this made him realize "that literary environmentalism was developing, de facto, as an offshoot of American studies" (Nixon, 2011, p. 234). Missing, Nixon realized, were the voices of postcolonial literary scholars. He points to the example of Ken Saro-Wiwa, an "Ogoni author who was being held prisoner without trial for his environmental and human rights activism in Nigeria" (Nixon, 2011, p. 234). Even following his death, which Nixon (2011) claims makes him "Africa's most visible environmental martyr," Saro-Wiwa's writings were "unlikely to find a home in the kind of environmental literary lineage" that had formed in the American vein (p. 234). This is because "the environmental justice movement" has become a "branch of American environmentalism" (Nixon, 2011, p. 235). Nixon (2011) laments that this high potential "for connecting outward internationally to issues of slow violence, the environmentalism of the poor, and imperial socioenvironmental degradation" continues to remain marginalized (p. 235). By maintaining an American centrality in environmentalism, one based in racism and exclusion of indigenous people, it is almost impossible for environmentalism to resist its imperialistic underpinnings.

The American focus of environmentalism is not the only complication to the potential postcolonial turn for global climate studies. The claim that colonialism is inextricably tied to climate change is not uncontested. In fact, Ghosh (2016) makes the surprising claim "that imperialism actually delayed the onset of the climate crisis by retarding the expansion of Asian and African economies" (pp. 109-10). He says that it is highly likely that "if the twentieth-century empires had been dismantled earlier, then the landmark figure of 350 parts per million of carbon dioxide in the atmosphere would have been crossed long before it actually was" (Ghosh, 2016, p. 110). Therefore, instead of placing the blame on the West for adopting and maintaining "some of the key technologies of the carbon economy...the world's leading colonial power may 
eTropic 20.2 (2021) Special Issue: Tropical Imaginaries and Climate Crisis

actually have retarded the onset of the climate crisis" [emphasis in original] (Ghosh, 2016, p. 110). This controversial claim seems to reinscribe the ideology that colonization was necessary or even beneficial. Furthermore, this romanticization of the pre-colonial past is not accurate across all settings. Take, for example, Easter Island. Despite its pre-industrial, pre-colonial state, Easter suffered the devastating effects of overharvesting, overfishing, and deforestation. The native population of Easter decimated their food sources until "[o]f the 25 or more formerly breeding sea birds, overharvesting and rat predation brought the result that 24 no longer breed on Easter itself" and "[e]ven the shellfish were overexploited" (Diamond, 2005, p. 106). In order to make boats for fishing, make firewood, and clear land for gardens, the population of Easter also began a process of "[d]eforestation [that] must have begun sometime after human arrival by A.D. 900, and must have been completed by 1722" (Diamond, 2005, p. 106-7). Diamond (2005) argues that this level of natural destruction ranks itself as "the most extreme example of forest destruction in the Pacific, and among the most extreme in the world" (p. 107). Of course, it is naïve to believe that postcolonial nations, left to develop on their own, would have industrialized in a manner matching the natural exploitation and destruction of Easter Island. Furthermore, Ghosh's claim minimizes the damage Western imperial economies have done. Ghosh assumes that if postcolonial nations had not had their industrialization restricted or altered by colonial forces then the carbon footprint of postcolonial nations would be greater than what the West caused during its imperialist actions in these areas. This is unlikely due to the nature of franchise colonialism, which demands the mass exploitation and consumption of natural resources to enrich the colonizer.

Additionally, Ghosh's claim ignores the possibility that the Global South, if never colonized by Western societies, would have developed practices that were as openly hostile to the environmental world as capitalism and consumerism. As Ghosh (2016) himself points out, "Imperialism was not, however, the only obstacle in Asia's path to industrialization: this model of economy met with powerful indigenous resistances of many kinds" (p. 111). In India, this indigenous resistance included prominent figures, like Mahatma Gandhi, who, understood "that the universalist premise of industrial civilization was a hoax; that a consumerist mode of existence, if adopted by a sufficient number of people would quickly become unsustainable and would lead, literally, to the devouring of the planet" (Ghosh, 2016, pp. 111-2). It is possible that imperialism did delay the onset of these countries' contributions to the climate crisis. However, if they had never been colonized, their own industrialization process may have contributed to the crisis to a much smaller degree due to potential innovation and greener alternatives they were not allowed to develop independently. This is supported by the rapid development of sustainable technology in Singapore. The formerly colonized country is leading Southeast Asia-and even many western 
eTropic 20.2 (2021) Special Issue: Tropical Imaginaries and Climate Crisis

nation-in sustainable innovation. Additionally, early this year, "the city-state's government launched a whole-of-nation sustainable development agenda: Green Plan 2030" (Mulia, 2021). This example is why many scholars and activists are pushing to decolonize the conversation and practices surrounding the fight against global climate change.

The push to decolonize the climate crisis largely coincides with a resurgence in indigenous knowledge. Some of the earliest environmental activism in recent memory has been against deforestation in the Amazon rainforest, which has historically been-and continues to be-led by indigenous activists from South America. These tropical indigenous activists have lain the groundwork for more modern indigenous resistance. Kyle Powys Whyte (2017), a citizen of the Potawatomi nation, states that "[i]ndigenous peoples are emerging as among the most audible voices in the global climate justice movement" (p. 88). Whyte highlights the indigenous presence at both the 2015 United Nations Climate Change Conference of the Parties (COP) in Paris and the Rio+20 Earth Summit in 2012 where representatives intended "to discuss and express their concerns about sustainable development and climate change" (2017,p. 94). Perhaps the most welldocumented example of indigenous environmental resistance to policies that would harm the environment and exacerbate global climate change was the international fight against the Keystone $\mathrm{XL}$ pipeline. Keystone $\mathrm{XL}$, a "2,735-kilometre pipeline project by Calgary-based TransCanada" was projected to "carry roughly 800,000 barrels of oil a day from Alberta to refineries along the Texas Gulf Coast" (Fontaine, 2017). Environmental and indigenous resistance to the pipeline delayed its construction initially, and these groups vowed to continue fighting the construction when it was greenlit by the Trump administration in 2017. The Keystone XL pipeline's construction permit was rescinded by President Biden during his first day in office and activists are hopeful that this move will prevent future plans of reviving the project (Davenport, 2021). As with the similar Dakota Access pipeline (DAPL), indigenous groups led the fight against these destructive policies and were successful in preventing further environmental damage. These examples support the idea that indigenous industrialization would not have followed the same (or a more destructive) path as capitalist, consumerist development. Indigenous resistance to environmental damage also reinforces "how colonialism and capitalist economics facilitate the role of rich, industrialised countries and transnational corporations in bringing about risky climate change impacts" (Whyte, 2017, p. 94), reinscribing imperial devastation. The rise of indigenous resistance to the global climate crisis and the fact that climate change and imperialism are inextricably linked demonstrate that the only way to provide a stable, lasting solution is through anti-colonial climate studies. 
eTropic 20.2 (2021) Special Issue: Tropical Imaginaries and Climate Crisis

This ecocritical-postcolonial union is already emerging within the critical and creative writings of those from postcolonial nations. Daniel Arbino (2019) argues for a need to incorporate ecocritical, particularly ecogothic, frameworks into the analysis of Caribbean literature due to repeated environmental exploitation dating back to 1492 and continuing to this day. Hannah Regis (2020) builds on DeLoughrey and Handley's Postcolonial Ecologies to emphasize the "historical links between corporate capital systems, industrial toxics, deforestation, climate change and modern progress" (p. 154). She highlights the work of Olive Senior, a Jamaican poet, who "aims to contribute new understandings on Caribbean environmental and territorial justice" by "reviving indigenous folkways via the creative and mythic imagination" (Regis, 2020, p. 164). Similarly, Gregory Luke Chwala (2019) traces the "decolonial queer ecologies" reflected in the work of Michelle Cliff that serve to further decolonial efforts and redefine nature in a postcolonial space (p. 143). Furthermore, Craig Santos Perez (2020), a Chamoru poet from Guam, uses his poetry to highlight issues of climate change, capitalist exploitation, and militarization from an indigenous perspective. That these scholars and writers are rising up from tropical nations that have faced the longest and most intense colonialism is not a coincidence. This demonstrates the necessity to integrate postcolonial and ecocritical studies. Additionally, these works also demonstrate that this emerging ecocritical-postcolonial union can (and should) be led by indigenous scholars.

Despite the Global South's growing industrialization, Northern and Western civilizations remain among the world's top contributors of carbon emissions on a per capita basis of population. Environmentalism and conservation have a long and sordid past, particularly when it comes to postcolonial nations and ideologies. The formation of America's national parks was steeped in ideologies that reinforced purity and virgin landscapes, to the detriment of the indigenous populations that lived on these lands over thousands of years. Likewise, ecocriticism began and remains to this day American-centric. This sordid past, combined with the positioning of global climate change as a form of slow violence that will follow the pathways of imperialism and rewrite much of that period's destruction, places ecocriticism and postcolonial studies in a somewhat uncomfortable partnership. By acknowledging this-and using a postcolonial lens to view the impending threat of climate change-postcolonial literary thought might be an integral way to shift the focus within ecocritical work and make a larger impact within the humanities regarding climate change. Of course, even this might not be enough. Klein (2014) points out that signs indicate that climate change, "rather than sparking solutions that have a real chance of preventing catastrophic warming and protecting us from inevitable disasters" will instead "once again be seized upon to hand over yet more resources to the 1 percent" (p. 8). To try and prevent the world's elite from taking economic, social, and political advantage of those most vulnerable to the effects of climate change, an anti-colonial climate 
eTropic 20.2 (2021) Special Issue: Tropical Imaginaries and Climate Crisis

studies viewpoint becomes imperative. That is the only hope for avoiding the missteps of the past and preventing the worst of the catastrophic future that is looming on the horizon. 
eTropic 20.2 (2021) Special Issue: Tropical Imaginaries and Climate Crisis

\section{References}

Arbino, D. (2019). "The ugliness of my surroundings": Tip Marugg's Ecogothic Poetics of Isolation. eTropic: electronic journal of studies in the Tropics 18(1), 125-140. https://doi.org/10.25120/etropic.18.1.2019.3668.

BBC News. (2018, Aug. 29). Puerto Rico increases Hurricane Maria death toll to 2,975. https://www.bbc.com/news/world-us-canada-45338080.

Chakrabarty, D. (2012). Postcolonial studies and the challenge of climate change. New Literary History, 43(1), 1-18. https://doi.org/10.1353/nlh.2012.0007

Chwala, G. L. (2019). Ruins of Empire: Decolonial Queer Ecologies in Cliff's No Telephone to Heaven. eTropic: electronic journal of studies in the Tropics 18(1), 141-156. https://doi.org/10.25120/etropic.18.1.2019.3690.

Coto, D. (2017, Dec. 29). Anger grows as half of Puerto Rico remains without power months after hurricane. Time. http://time.com/5082225/hurricane-maria-puerto-rico-nopower/.

Davenport, C. (2021, June 19). The Keystone XL pipeline project has been terminated. The New York Times. https://www.nytimes.com/2021/06/09/business/keystone-xlpipeline-canceled.html.

DeLoughrey, E. \& Handley, G.B. (2011). Introduction: Toward an aesthetics of the earth. In DeLoughrey, E. \& Handley, G.B. (Eds.) Postcolonial Ecologies: Literatures of the Environment (pp. 3-39). Oxford UP. https://doi.org/10.1093/acprof:osobl/9780195394429.003.0001

Diamond, J. (2005). Collapse: How societies choose to fail or succeed. Viking.

Edwards, J. D. (2008). Postcolonial literature. Palgrave Macmillan.

Fontaine, T. (2017, May 27). 'A perilous pipeline': Indigenous groups line up against Keystone XL. CBC. https://www.cbc.ca/news/indigenous/indigenous-groupskeystonexl-2017-approval-1.4042381.

Ge, M., Friedrich J., \& Damassa T. (2014, Nov. 25). 6 Graphs explain the world's top 10 emitters. World Resources Institute. https://wri.org/blog/2014/11/6-graphs-explainworld\%E2\%80\%99s-top-10-emitters.

Ghosh, A. (2016). The great derangement: Climate change and the unthinkable, $\mathrm{U}$ of Chicago P. https://doi.org/10.7208/chicago/9780226323176.001.0001

Harvard University Press. (2013, Nov. 14). When slow violence sprints [Interview with R. Nixon]. https://harvardpress.typepad.com/hup publicity/2013/11/when-slow-violencesprints-rob-nixon.html

Hurricane Maria 2017. Climate Signals, Climate Nexus. http://www.climatesignals.org/headlines/events/hurricane-maria-2017.

Klein, N. (2014). This changes everything: Capitalism vs. the climate. Simon \& Schuster. Memmi, A. (1991). The Colonizer and the Colonized. Beacon.

Mulia, K. (2021, Feb. 19). With new national plan, Singapore leads region's sustainable green tech innovations. KrAsia, https://kr-asia.com/with-new-national-plan-singaporeleads-regions-sustainable-green-tech-innovations.

Nixon, R. (2011). Slow violence and the environmentalism of the poor. Harvard UP. https://doi.org/10.4159/harvard.9780674061194

Nunez, C. (2017, March 28). China poised for leadership on climate change after U.S. reversal. National Geographic. https://news.nationalgeographic.com/2017/03/chinatakes-leadership-climate-change-trump-clean-power-plan-paris-agreement/.

Office of Special Investigations, Office of Inspector General, U.S. Department of Housing and Urban Development, (2021). Review of HUD's Disbursement of Grant Funds Appropriated for Disaster Recovery and Mitigation Activities in Puerto Rico (Report No. 2019SU008945I). Author. 
eTropic 20.2 (2021) Special Issue: Tropical Imaginaries and Climate Crisis

Perez, C. S. (2020). Poems. eTropic: electronic journal of studies in the Tropics 19(1), 4264. https://doi.org/10.25120/etropic.19.1.2020.3676.

Regis, H. (2020). Subjection and Resistance: Landscapes, Gardens, Myths and Vestigial Presences in Olive Senior's Gardening in the Tropics. eTropic: electronic journal of studies in the Tropics 19(1), 151-166. https://doi.org/10.25120/etropic.19.1.2020.3682.

Robles, F., Davis K., Fink S., \& Almukhtar S. (2017, Dec. 9). Official toll in Puerto Rico: 64. Actual deaths may be 1,052. New York Times. https://www.nytimes.com/interactive/2017/12/08/us/puerto-rico-hurricane-mariadeath-toll.html? $r=0$.

Sealy-Huggins, L. (2017). " $1.5^{\circ} \mathrm{C}$ to stay alive": climate change, imperialism and justice for the Caribbean." Third World Quarterly, 38(11), 2444-2463, https://doi.org/10.1080/01436597.2017.1368013

Spence, M. D. (1999). Dispossessing the wilderness: Indian removal and the making of the national parks. Oxford UP.

Squarzoni, P. (2014). Climate Changed: A Personal Journey through the Science. Harry N. Abrams.

Vick, K. (2017, Oct. 3). A land they no longer recognize: Desperation and resilience in hurricane-battered Puerto Rico. Time, http://time.com/a-land-they-no-longerrecognize/.

Whyte, K. P. (2017). Is it colonial déjà vu?: Indigenous peoples and climate injustice. In J. Adamson \& M. Davis (Eds.), Humanities for the Environment: Integrating Knowledge, Forging New Constellations of Practice (pp. 88-105). Routledge.

\section{Acknowledgments}

I would like to thank Dr Terry Harpold for his feedback on this article when it was a seminar paper. I also want to thank Jennifer Murray for her help and support during the writing and revision processes. Finally, I want to thank the anonymous reviewers for their constructive feedback and Anita Lundberg for her editor comments.

Rachel Hartnett is a doctoral candidate in the Department of English at the University of Florida. Her dissertation, titled "Base Camp Literature: US Structures of Franchise and Settler Colonialism", focuses on texts written by native and indigenous writers living in spaces occupied by the U.S. military. She earned her M.A. in English in 2016 from Florida Atlantic University. Her article, "The Silver Queen': U.S. Imperialism and A Song of Ice and Fire" was recently published with the Journal of Popular Culture. 